\title{
Genetic Evaluation of Dairy Sires for Milking Duration Using Electronically Recorded Milking Times of Their Daughters
}

\author{
N. R. Zwald, ${ }^{1}$ K. A.Weigel, ${ }^{2}$ Y. M. Chang, ${ }^{1}$ R. D. Welper, ${ }^{2}$ and J. S. Clay ${ }^{3}$ \\ ${ }^{1}$ University of Wisconsin, Department of Dairy Science, Madison 53706 \\ ${ }^{2}$ Alta Genetics, Inc., Watertown, WI 53094 \\ ${ }^{3}$ Dairy Records Management Systems, Raleigh, NC 27695
}

\section{ABSTRACT}

The potential of using electronically recorded data from on-farm milking parlor and herd management software programs for genetic evaluation of dairy sires for milking duration of their daughters was assessed in the present study. Single measurements of milking duration were collected weekly from 29 herds between June 1, 2003 and April 1, 2004. These included 73,547 observations corresponding to 10,152 Holstein cows from 1551 sires. Average milking duration for a single milking in our data set was 4.5 min. Estimated heritability of milking duration was 0.17 , and predicted transmitting abilities (PTA) of individual sires ranged from $-0.48 \mathrm{~min}$ for sires with the fastest milking daughters to 0.59 min for sires with the slowest milking daughters. The correlation between PTA for milking duration and PTA for somatic cell score (SCS) was -0.15 , indicating that sires whose daughters milk most quickly also tend to transmit higher SCS to their progeny. Correlations between PTA milking duration and PTA for teat placement and teat length were -0.14 and 0.20 , respectively, indicating that sires that transmit wide teat placement and long teats tend to have daughters that milk slowly. Based on the results presented herein, it appears that genetic selection based on objective, electronically recorded milking times is possible. This approach would greatly improve the quality and efficiency of data collection relative to conventional evaluations of milking speed, which are based on farmer surveys. The number of herds currently equipped to routinely capture milking times is limited, but this number is increasing very rapidly. Future research should focus on refinement of data reporting and validation systems, as well as estimation of the economic value of milking duration. This trait may have an intermediate optimum, because cows that milk too slowly will disrupt parlor flow and reduce

Received June 9, 2004.

Accepted September 27, 2004.

Corresponding author: K. Weigel; e-mail: kweigel@wisc.edu. milking efficiency, but cows that milk too quickly may be at greater risk for mastitis.

(Key words: milking speed, milking duration, genetic selection, dairy sire)

Abbreviation key: $\mathbf{M D}=$ milking duration, $\mathbf{M S}=$ milking speed.

\section{INTRODUCTION}

Genetic information regarding milking speed (MS) or milking duration (MD) of the progeny of US dairy sires has been available for many years. However, this information comes in the form of survey data, obtained via direct mailings to dairy producers or face-to-face interviews of dairy producers by AI stud or breed association personnel. Because these data are reported in a subjective manner, the MS or MD observations of individual animals are exposed to many potential sources of bias and error. Furthermore, genetic evaluations of dairy sires are calculated independently within each AI organization, so it is impossible to compare sires from different studs.

Smith et al. (1985) and Lawstuen et al. (1988) each reported heritability estimates for MS of 0.11 based on a single observation per animal; however, both noted that collection of multiple, repeated observations per animal would be ideal. Meyer and Burnside (1987) also concluded that a single MS observation per animal may be insufficient, because genetic and environmental factors that affect the MS of individual cows may vary during a lactation or between subsequent lactations.

Moore et al. (1983) noted that the accuracy of MS evaluations could be improved if objective measures of this trait became available. They recorded the volume of milk produced by an individual cow during a 2-min period, as well as the total MD of each animal. Estimated heritability of the "2-min milk" was 0.23 , which was significantly higher than the corresponding estimate of 0.13 for MD.

Until recently, computer technology in milking parlors has not allowed easy, routine storage of MD or other measures of MS, such as peak flow rate. There- 
fore, genetic evaluations of dairy sires continue to rely on subjectively collected survey data. Unfortunately, the accuracy of survey data has deteriorated rapidly as the size of progeny test herds has increased. In many cases, the owners or herdsmen who complete the surveys are not routinely involved in milking these animals, so they cannot formulate accurate assessments of the MS of individual cows. On many modern dairies, owners and herdsmen focus on group measures of parlor efficiency, such as the number of "turns" per hour or the number of cows milked per hour. Milking duration may have an intermediate optimum, because most producers prefer cows with relatively uniform MD that do not decrease the flow of cows through the milking parlor. However, selection for extremely short MD (i.e., fast milkers) may be undesirable, because an antagonistic relationship may exist between MD and SCS (Zhang et al., 1994).

The objective of the present study was to determine the usefulness of electronically recorded MD data from parlor management software programs for routine genetic evaluation of dairy sires. In addition, we sought to assess the relationships between $\mathrm{MD}$ and other economically important traits, such as production, conformation, and health.

\section{MATERIALS AND METHODS}

Data were collected from June 1, 2003 to April 1, 2004 in 29 herds that participated in the Alta Genetics Advantage Progeny Testing Program. These herds were located in the following states: California ( $\mathrm{n}=$ $1)$, New York $(\mathrm{n}=5)$, Pennsylvania $(\mathrm{n}=4)$, Michigan $(\mathrm{n}=2)$, Minnesota $(\mathrm{n}=3)$, Iowa $(\mathrm{n}=1)$, Washington $(\mathrm{n}=1)$, and Wisconsin $(\mathrm{n}=12)$. All herds used milking parlor equipment and software from Bou-Matic (Madison, WI), Westphalia-Surge (Naperville, IL), DeLaval (Kansas City, MO), or Germania (Waunakee, WI). In addition, all herds used the Dairy Comp 305 program (Valley Ag Software, Tulare, CA) for overall dairy herd management. A summary of the data is provided in Table 1.

Data were collected directly from the Dairy Comp 305 software program on each farm; therefore, proper configuration of the interface between the herd management software program and the parlor software program was critical. An electronic measurement of MD was taken for every cow at every milking; however, these observations are routinely overwritten at the next milking. Therefore, a "scheduled task" was configured in each herd, such that MD observations for a selected milking each week were exported for external storage. As a result, each cow had one MD observation per week. The particular milking that was selected
Table 1. Summary of milking duration data, based on a single measurement per cow per week.

\begin{tabular}{lc}
\hline Variable & No. \\
\hline Total observations & 73,547 \\
Total lactations & 14,844 \\
Total cows & 10,152 \\
Total herds & 29 \\
Total sires & 1551 \\
Mean observations/lactation & 5.0 \\
Mean lactations/cow & 1.5 \\
Mean cows/herd & 350 \\
Mean daughters/sire & 6.5 \\
\hline
\end{tabular}

varied between herds, but data were always collected at the same day and time within an individual herd. For example, in a herd in which the "scheduled task" was set to occur at noon on Mondays, the MD measurements for all cows corresponded to the Monday morning milking.

Individual MD observations were subsequently matched with individual milk weights from the same milking. This process allowed the inclusion of milk yield as a covariate in our analysis of MD data. After removing records from cows that did not have an identified AI sire and cows whose sire had $<5$ total daughters in the data set, a total of 73,547 records from 10,152 cows and 1551 sires remained for analysis. A Fortran 90 program was developed for the Bayesian analysis described subsequnetly. Gibb's sampling was used, with bounded uniform priors for fixed effects, normal priors for random effects, and scaled, inverted $\chi^{2}$ priors for variance components. The model for MD was as follows:

$$
\begin{gathered}
\mathrm{y}_{\mathrm{ijklmno}=\mu}+\mathrm{P}_{\mathrm{i}}+\mathrm{MF}_{\mathrm{j}}+\mathrm{DIM}_{\mathrm{k}}+\mathrm{htd}_{\mathrm{l}}+\mathrm{s}_{\mathrm{m}}+\mathrm{c}_{\mathrm{mn}} \\
+\beta \times \mathrm{MY}_{\mathrm{ijklmno}}+\mathrm{e}_{\mathrm{ijklmno}}
\end{gathered}
$$

where

$$
\begin{aligned}
\mathrm{y}_{\mathrm{jklmno}}= & \text { MD observation for a particular cow in a } \\
& \text { given week; } \\
\mu= & \text { population mean; } \\
\mathrm{P}_{\mathrm{i}}= & \text { fixed effect of parity (primiparous or mul- } \\
& \text { tiparous); } \\
\mathrm{MF}_{\mathrm{j}}= & \text { fixed effect of milking frequency }(2 \times \text { or } \\
& 3 \times) ; \\
\mathrm{DIM}_{\mathrm{k}}= & \text { fixed effect of DIM class ( } 1 \text { to } 10,11 \text { to } \\
& 60,61 \text { to } 110,111 \text { to } 160,161 \text { to } 210,211 \\
& \text { to } 260,261 \text { to } 310,311 \text { to } 360, \text { or } 361 \text { to } \\
& 390 \text { d postpartum); } \\
\operatorname{htd}_{\mathrm{l}}= & \text { random effect of herd-test date (of mea- } \\
& \text { surement), distributed as } \mathrm{N}\left(\mathbf{0}, \mathbf{I} \sigma_{\mathrm{h}}^{2}\right) ;
\end{aligned}
$$




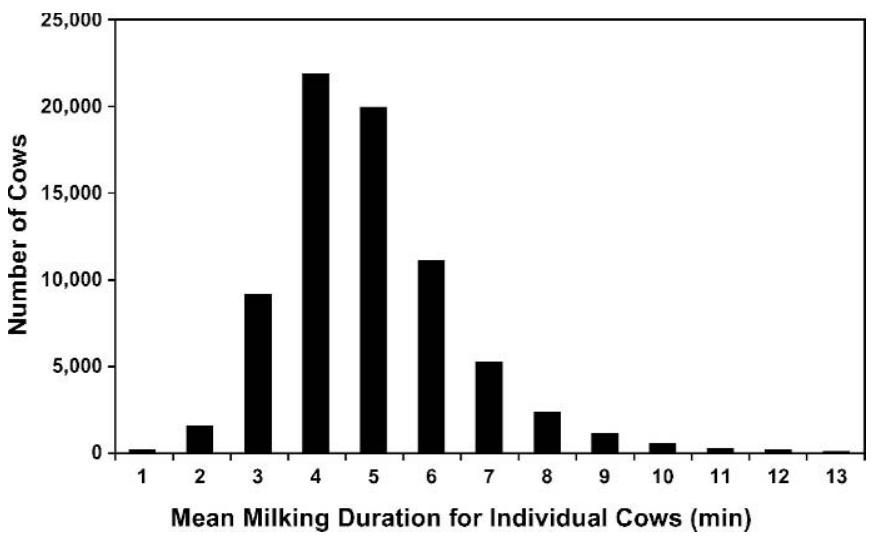

Figure 1. Distribution of the mean of single, weekly measurements of milking duration for individual cows in the present study.

$\mathrm{S}_{\mathrm{m}}=$ random effect of sire, distributed as $\mathrm{N}(\mathbf{0}$, $\left.\mathbf{A} \sigma_{\mathrm{s}}^{2}\right)$

$\mathrm{c}_{\mathrm{mn}}=$ random effect of cow, nested within sire, distributed as $\mathrm{N}\left(\mathbf{0}, \mathbf{I} \sigma_{\mathrm{c}}^{2}\right)$;

$\mathrm{MY}_{\mathrm{ijklmno}}=$ fixed effect of test-day milk yield (when MD data were collected), with corresponding regression coefficient $\beta$, and

$\mathrm{e}_{\mathrm{ijk} k \mathrm{mno}}=$ random residual, distributed as $\mathrm{N}\left(\mathbf{0}, \mathbf{I} \sigma_{\mathrm{e}}^{2}\right)$

The first DIM class covered a shorter time period, because certain factors that influence MD, such as parlor training of primiparous cows, occur early in the lactation. Because MD were available for only a 10mo period, very few dams and granddams of animals in our study had MD information of their own. Therefore, we chose a sire model, rather than an animal model. However, an animal could be applied in the future, when more records on animals from multiple generations become available.

\section{RESULTS AND DISCUSSION}

As shown in Table 1, each cow had an average of 5.0 MD observations during the 10-mo period of this study; these were distributed across 1.5 lactations per cow. Although only 29 herds provided data, these herds tended to be large, with an average of 350 cows per herd. Mean number of progeny per sire was low, approximately 6.5 , but this number will increase rapidly in the future, as Alta Genetics concentrates its progeny testing efforts in Advantage Program herds.

The phenotypic average MD in this study was 4.5 min, as shown in Figure 1, but means for individual cows ranged from 1 to $13 \mathrm{~min}$. As is the case for many "time-to-event" variables, the distribution of MD ob-

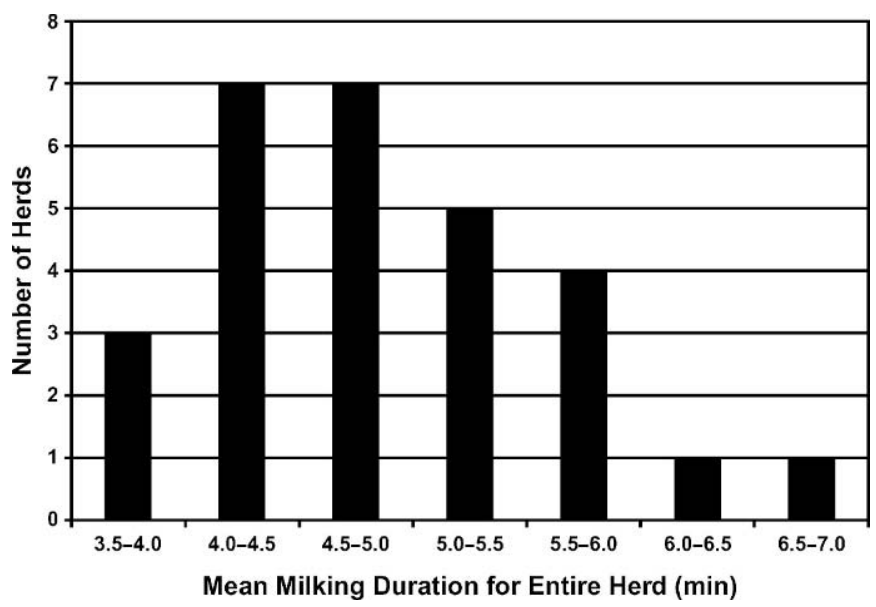

Figure 2. Distribution of the mean of single, weekly measurements of milking duration for entire herds in the present study.

servations was slightly skewed to the right, and future studies may wish to consider transforming the data to achieve normality. As shown in Figure 2, the range in herd means for MD was approximately 2 -fold, from 3.5 to $7.0 \mathrm{~min}$. Therefore, one can conclude that herd management variables, such as parlor design, employee training, etc., can have a major impact on MD. The trajectory of MD observations, calculated as monthly means, is shown in Figure 3. Not surprisingly, the shape of the MD curve tends to be similar to that of a typical lactation curve for milk yield. This is logical because MS of a given cow is expected to be relatively constant across lactation, and MD is thus increased when the quantity of milk to be released is greater.

The estimated heritability of MD was 0.17 , as shown in Table 2. This estimate was similar to those previously reported by Boettcher et al. (1998), Meyer and Burnside (1987), and Rupp and Boichard (1999) for subjectively scored MS. Fixed-effect solutions for parity, milking frequency, and DIM are shown in Table 3. The regression of MD on daily milk yield was positive, $0.147 \mathrm{~min} / \mathrm{kg}$, indicating that higher milk yield is associated with longer MD. Mean MD was slightly shorter for primiparous cows, relative their multiparous herdmates, and mean MD for herds (or animals) milked 3 times daily tended to be shorter than for those milked 2 times daily. Solutions for DIM classes tended to follow the same trajectory as the raw means shown in Figure 3.

Sire PTA for MD, which were expressed as deviations from the phenotypic average of $4.5 \mathrm{~min}$, are shown in Figure 4. Negative sire PTA corresponded to shorter MD (faster milking daughters) and positive PTA corresponded to longer MD (slower milking 


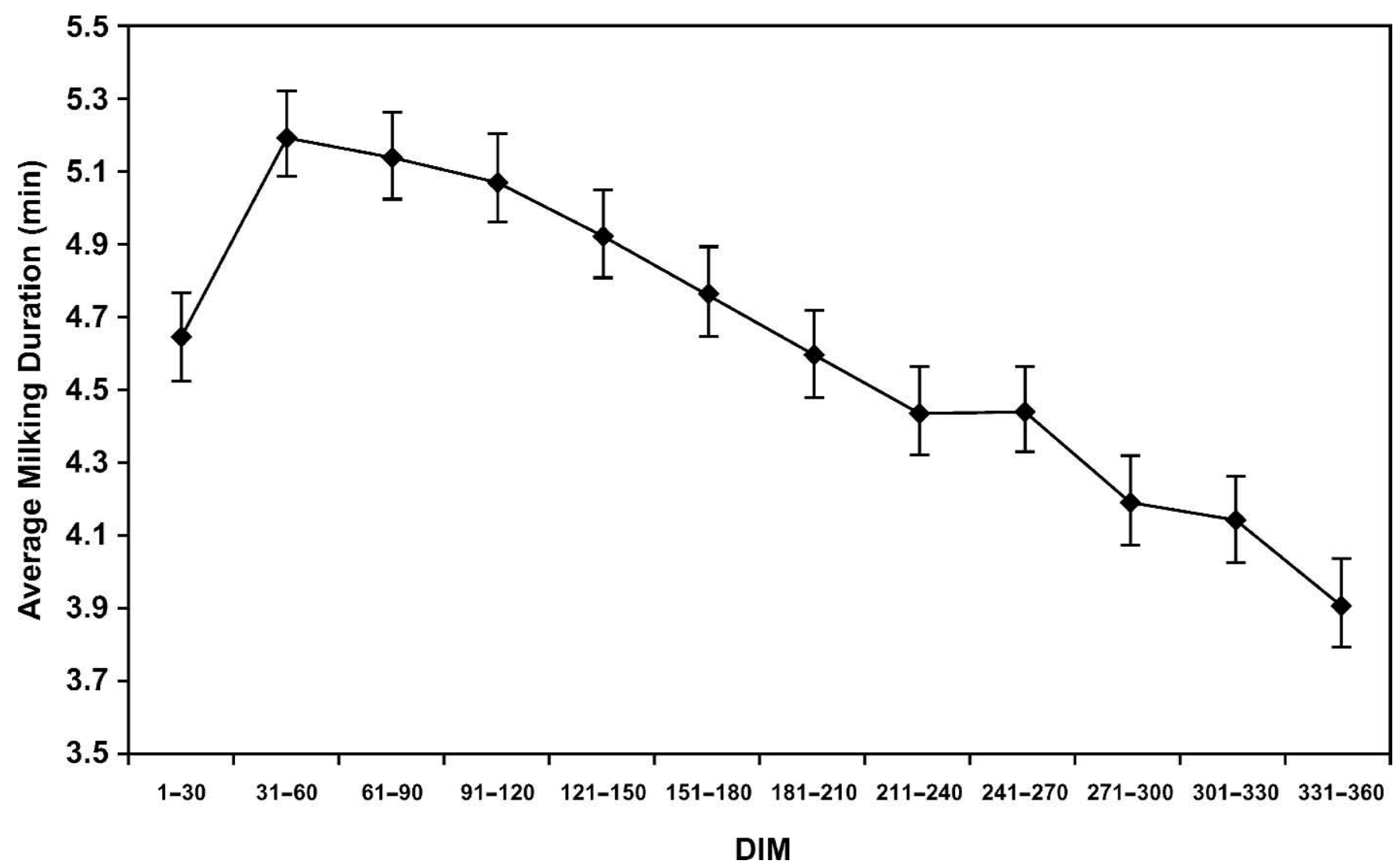

Figure 3. Trajectory of milking duration over the course of lactation, based on the mean of of single, weekly measurements for cows in the present study.

daughters). Sire PTA for MD ranged from $-0.48 \mathrm{~min}$ for the sire with fastest milking daughters to $0.59 \mathrm{~min}$ for the sire with slowest milking daughters. Sire PTA had a reasonably normal distribution, and the SD of sire PTA was $0.18 \mathrm{~min}$.

Correlations between sire PTA for MD and sire PTA for other economically important traits, as calculated by the USDA Animal Improvement Programs Laboratory (Beltsville, MD) and the Holstein Association USA, Inc. (Brattleboro, VT), are presented in Table 4. Note that product-moment correlations between sire

Table 2. Estimated genetic parameters for milking duration, based on a single measurement per cow per week.

\begin{tabular}{lll}
\hline Parameter & $\begin{array}{l}\text { Posterior } \\
\text { mean }\end{array}$ & $\begin{array}{l}\text { Posterior } \\
\mathrm{SD}\end{array}$ \\
\hline Herd-test date variance $\left(\mathrm{min}^{2}\right)$ & 1.13 & 0.18 \\
Sire variance $\left(\mathrm{min}^{2}\right)$ & 0.09 & 0.03 \\
Cow variance $\left(\mathrm{min}^{2}\right)$ & 1.01 & 0.02 \\
Residual variance $\left(\mathrm{min}^{2}\right)$ & 1.00 & 0.01 \\
Heritability & 0.17 & 0.03 \\
\hline
\end{tabular}

PTA are strongly influenced by reliability. Because the average number of progeny per sire in MD evaluations was quite small, the correlations shown in Table 4 are likely to be lower in magnitude than true genetic correlations between the traits. Nonetheless, the di-

Table 3. Fixed effect solutions for milking duration, based on a single measurement per cow per week.

\begin{tabular}{lcl}
\hline Effect & Level & $\begin{array}{l}\text { Solution } \\
(\mathrm{min})\end{array}$ \\
\hline Daily milk yield & & $0.147(\mathrm{~min} / \mathrm{kg})$ \\
Parity & 1st & 1.15 \\
& Later & 1.21 \\
Milking frequency & $2 \times$ & 3.08 \\
& $3 \times$ & 2.57 \\
DIM & $0-10$ & 4.33 \\
& $11-60$ & 4.68 \\
& $61-110$ & 4.63 \\
& $111-160$ & 4.45 \\
& $161-210$ & 3.32 \\
& $211-260$ & 4.29 \\
& $261-310$ & 4.21 \\
& $311-360$ & 4.13 \\
\hline
\end{tabular}




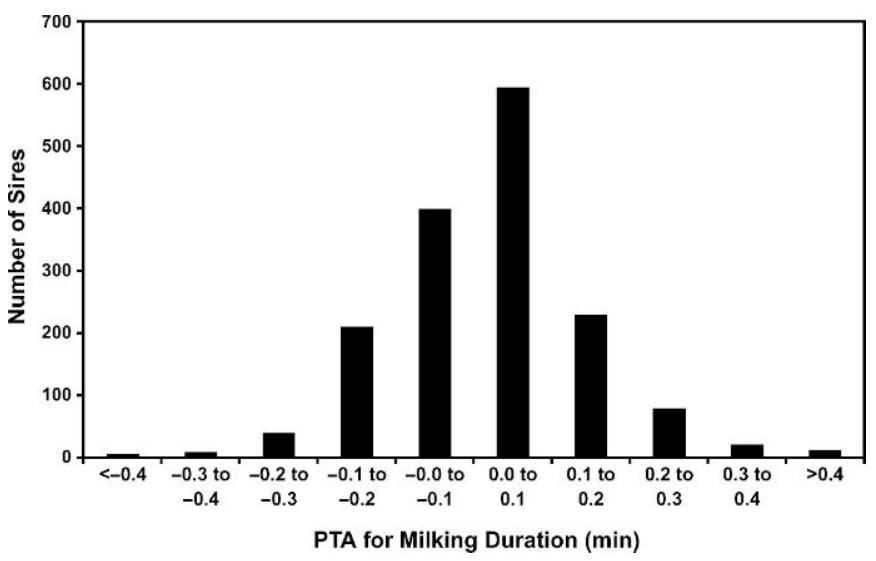

Figure 4. Distribution of predicted transmitting abilities (PTA) of individual Holstein sires for milking duration of their daughters.

rection of these correlations may be of interest, at least for those correlations that were significantly significant. Correlations between PTA for MD and PTA for udder traits tended to be slightly negative, and a significant negative relationship $(P<0.05)$ was observed between $\mathrm{MD}$ and front teat placement, indicating that cows with wider front teats had longer MD. In addition, a significant positive relationship $(P<0.05)$ was found between $\mathrm{MD}$ and teat length, indicating that cows with longer teats had longer MD. When sires were divided into groups based on PTA for MD (sires $>1$ SD below the mean, sires between 1 SD below and 1 SD above the mean, and sires $>1$ SD above the mean),

Table 4. Product-moment correlations between PTA for milking duration $\left(\mathrm{PTA}_{\mathrm{MD}}\right)$ from the present study and PTA for other traits routinely evaluated in US Holstein sires.

\begin{tabular}{lc}
\hline & $\begin{array}{l}\text { Correlation } \\
\text { with }\end{array}$ \\
Trait & PTA $_{\mathrm{MD}}$ \\
\hline Milk yield & -0.05 \\
Fat percentage & 0.00 \\
Protein percentage & 0.03 \\
Somatic cell score & $-0.15^{*}$ \\
Productive life & -0.10 \\
Daughter pregnancy rate & -0.09 \\
Clinical mastitis ${ }^{1}$ & -0.09 \\
Fore udder attachment & -0.07 \\
Rear udder height & 0.03 \\
Rear udder width & -0.02 \\
Udder cleft & -0.07 \\
Udder depth & -0.08 \\
Front teat placement & $-0.14^{*}$ \\
Teat length & $0.20^{*}$ \\
\hline
\end{tabular}

${ }^{1}$ Predicted transmitting abilities for clinical mastitis were from Zwald et al. (2004).

*Significantly different from zero $(P<0.05)$. similar trends were observed in mean sire PTA for the udder traits, as shown in Table 5.

The estimated correlation between PTA for MD and PTA for SCS was -0.15 (Table 4), meaning that sires that transmit shorter MD tend to transmit higher SCS $(P<0.05)$. Therefore, if selection were practiced for lower MD without additional selection pressure on SCS, then SCS would likely increase over time. A similar relationship was observed in Table 5, where mean PTA for SCS was highest for sires with fast milking daughters and lowest for sires with slow milking daughters.

The estimated correlation between PTA for MD and PTA for clinical mastitis, as calculated by Zwald et al. (2004), was -0.09 but was not significantly different from zero $(P>0.05)$. Rupp and Boichard (1999) also reported an antagonistic relationship between MS and SCS, but no significant relationship between MS and clinical mastitis. However, in this study, the probability of clinical mastitis among daughters was slightly higher for sires that transmitted extremely fast or slow milking speed ( $>1 \mathrm{SD}$ above or below the mean), as compared with average sires, so a nonlinear relationship may exist. Increased incidence of clinical mastitis in slow milking cows could be due to incomplete milkout or irritated teat ends (because of extended milking time), or it is possible that cows that have previously been infected with mastitis tend to have longer milking duration (because of udder damage or injury). Similar results were reported by Seykora and McDaniel (1985).

Estimated correlations between PTA for MD and PTA for productive life and daughter pregnancy rate were favorable, although not significantly different from zero $(P>0.05)$. Sire PTA for productive life and daughter pregnancy rate were highest for sires with PTA for MD >1 SD below the mean. Correlations between PTA for MD and PTA for milk yield, fat percentage, and protein percentage were negligible, although the former was expected, given that milk yield was included as a covariate in the analysis.

Incorporating sire PTA for MD into a selection index may or may not be appropriate, because MD may have an intermediate optimum, and future work should focus on refining the economic value of this trait. It is likely that sires that transmit shorter milking duration would be favored, but these sires may transmit higher SCS if their daughters' teat openings do not close quickly and completely after milking. On the other hand, sires that transmit longer milking duration would generally be avoided, because their daughters would disrupt parlor flow and reduce parlor efficiency. A properly designed selection index including both SCS and MD may be ideal, inasmuch as it could 
Table 5. Mean PTA for traits routinely evaluated in US Holstein sires, according to category for PTA for milking duration $\left(\mathrm{PTA}_{\mathrm{MD}}\right)$ in the present study.

\begin{tabular}{|c|c|c|c|}
\hline \multirow[b]{2}{*}{ Trait } & \multicolumn{3}{|c|}{ Mean PTA } \\
\hline & $\begin{array}{l}\mathrm{PTA}_{\mathrm{MD}} \\
\geq 1 \mathrm{SD} \text { below } \\
\text { the mean } \\
\text { (fast) }\end{array}$ & $\begin{array}{l}\mathrm{PTA}_{\mathrm{MD}} \\
\text { within } \pm 1 \mathrm{SD} \\
\text { of the mean }\end{array}$ & $\begin{array}{l}\mathrm{PTA}_{\mathrm{MD}} \\
\geq 1 \mathrm{SD} \text { above } \\
\text { the mean } \\
\text { (slow) }\end{array}$ \\
\hline Milk yield, kg & 1095 & 1022 & 1020 \\
\hline Fat percentage, $\%$ & -0.008 & -0.024 & -0.018 \\
\hline Protein percentage, $\%$ & 0.008 & 0.011 & 0.012 \\
\hline Somatic cell score & 3.20 & 3.15 & 3.10 \\
\hline Productive life, mo & 0.83 & 0.32 & 0.50 \\
\hline Daughter pregnancy rate, $\%$ & 0.33 & 0.04 & -0.04 \\
\hline Clinicial mastitis ${ }^{1}$ & 0.181 & 0.176 & 0.186 \\
\hline Fore udder attachment & 1.02 & 0.81 & 0.79 \\
\hline Rear udder height & 1.10 & 1.01 & 1.02 \\
\hline Rear udder width & 1.07 & 0.99 & 0.86 \\
\hline Udder cleft & 1.07 & 0.72 & 0.72 \\
\hline Udder depth & 0.80 & 0.62 & 0.60 \\
\hline Front teat placement & 1.28 & 0.77 & 0.66 \\
\hline Teat length & -0.36 & 0.02 & 0.32 \\
\hline
\end{tabular}

${ }^{1}$ Predicted transmitting abilities for clinical mastitis were from Zwald et al. (2004).

properly account for the relationships between the traits. Some countries are already using similar indexes with subjectively recorded MS (e.g., Boettcher et al., 1998).

\section{CONCLUSION}

The results of this study show that MD data can be collected electronically from herds using parlor management software and can be subsequently used for genetic selection purposes. Objective, electronically recorded MD data offer numerous advantages relative to subjective, survey data including greater efficiency of data collection, availability of quantitative values (rather than binary or categorical measures), and reduced opportunity for bias or error.

On the other hand, several potential challenges can be foreseen with respect to sire evaluation using electronically recorded MD data. First, a relatively small percentage of progeny test herds currently have milking parlor and herd management software programs that routinely provide such data. Second, Dairy Comp 305 software does not routinely store alternative measures of MD, such as peak flow rate or "2-min milk yield" (Moore et al., 1983). Third, methods for recording and storing MD data can differ between milking parlor and herd management software programs, and this creates inconsistencies in the type of MD data that are available from different herds. In fact, the estimated heritability for MD in this study was similar to previous estimates based on subjective measures of MS.

Despite these limitations, great potential exists for collection and analysis of a large quantity of objectively scored MD data. Average herd size in the US is increasing at a dramatic rate, and the proportion of progeny test daughters in herds with milking parlors is increasing as well. The vast majority of large dairy herds have on-farm computers, and a very small number of software vendors (e.g., Dairy Records Management Systems, Raleigh, NC; DHI-Provo, Provo, UT, and Valley Ag Software, Tulare, CA) control nearly $100 \%$ of this market. Lastly, the estimated heritability of MD is substantially higher than that of several other type, fitness, and reproduction traits that are currently used for sire selection in the United States. The potentially antagonistic relationship between SCS and MD should be investigated further, and appropriate economic weights for this trait should be determined, such that genetic selection programs for more rapid or uniform MD can be implemented.

\section{REFERENCES}

Banos, G., and E. B. Burnside. 1992. Genetic evaluation of Canadian dairy bulls for milking speed with an animal model. Can. J. Anim. Sci. 72:169-172.

Boettcher, P. J., J. C. M. Dekkers, and B. W. Kolstad. 1998. Development of an udder health index for sire selection based on somatic cell score, udder conformation, and milking speed. J. Dairy Sci. 81:1157-1168.

Lawstuen, D. A., L. B. Hansen, G. R. Steuernagel, and L. P. Johnson. 1988. Management traits scored linearly by dairy producers. J. Dairy Sci. 71:788-799.

Meyer, K., and E. B. Burnside. 1987. Scope of a subjective assessment of milking speed. J. Dairy Sci. 70:1061-1068.

Moore, R. K., B. W. Kennedy, E. B. Burnside, and J. E. Moxley. 1983. Relationships between speed of milking and somatic cell count and production in Holsteins. Can. J. Anim. Sci. 63:781789.

Rupp, R., and D. Boichard. 1999. Genetic parameters for clinical mastitis, somatic cell score, production, udder type traits, and 
milking ease in first lactation Holsteins. J. Dairy Sci. $82: 2198-2204$.

Seykora, A. J., and B. T. McDaniel. 1985. Heritabilities of teat traits and their relationships with milk yield, somatic cell count, and percentage of two-minute milk. J. Dairy Sci. 68:2670-2683.

Smith, S. P., F. R. Allaire, W. R. Taylor, H. E. Kaeser, and J. Conley. 1985. Genetic parameters and environmental factors associated with type traits scored on an ordered scale during first lactation. J. Dairy Sci. 68:2058-2071.
Zhang, W. C., J. C. M. Dekkers, G. Banos, and E. B. Burnside. 1994. Adjustment factors and genetic evaluation for somatic cell score and relationships with other traits of Canadian Holsteins. J. Dairy Sci. 77:659-665.

Zwald, N. R., K. A. Weigel, Y. M. Chang, R. D. Welper, and J. S. Clay. 2004. Genetic selection for health traits. I. Incidence rates, heritability estimates, and sire breeding values. J. Dairy Sci. 87:4287-4294. 